\title{
MAHKAMAH KONSTITUSI DALAM KONSTRUKSI SISTEM PERADILAN IMPEACHMENT
}

\author{
Misranto \\ Pusat Kajian Konstitusi Fakultas Hukum Universitas Merdeka Pasuruan \\ e-mail:misrantoumpas@yahoo.co.id
}

\begin{abstract}
ABSTRAK
Mahkamah Konstitusi merupakan institusi peradilan yang dipercaya oleh konstitusi (UUD 1945) untuk mengimplementasikan sistem peradilan impeachment. Peradilan impeachment dimulai dengan permintaan fatwa oleh Dewan Perwakilan Rakyat kepada Mahkamah Konstitusi. Kedudukan Dewan Perwakilan Rakyat dalam persidangan Mahkamah Konstitusi atau dalam sistem peradilan impeachment adalah sebagai pihak pemohon. Permohonan diajukan ke Mahkamah Konstitusi setelah Dewan Perwakilan Rakyat berpendapat bahwa Presiden dan/ atau Wakil Presiden telah melakukan pelanggaran yang disebutkan dalam Pasal 7A UUD 1945. Sedangkan putusan yang diberikan oleh Mahkamah Konstitusi menjadi bukti, bahwa Indonesia benar-benar sebagai negara yang berbentuk negara hukum. Kewenangan Mahkamah Konstitusi dalam sistem peradilan impeachment baru bisa dijalankan, bilamana Dewan Perwakilan Rakyat mengajukan permohonan padanya. Kalau Dewan Perwakilan Rakyat tidak mengajukannya, maka sistem peradilan impeachment tidak akan terwujud.
\end{abstract}

Kata Kunci: impeachment, Mahkamah Konstitusi, demokrasi.

\section{ABSTRACT}

The Constitutional Court is a judicial institution that is trusted by the constitution (UUD 1945) to implement the impeachment court sistem. Justice impeachment begins with a request fatwa by the House of Representatives to the Constitutional Court. Position of the House of Representatives at the hearing of the Constitutional Court or the judicial sistem of impeachment is the applicant. Application is submitted to the Constitutional Court after the House of Representatives argued that the President and/or Vice-President has committed an offense referred to in Article $7 A$ of the 1945 Constitution. While the verdict given by the Constitutional Court is proof that Indonesia is really a form of state law countries. Authority of the Constitutional Court in the impeachment court sistem can only be executed, if the House of Representatives to apply to him. If Parliament does not propose, then the justice sistem impeachment will not be realized.

Keywords: impeachment, the Constitutional Court, democracy.

\section{PENDAHULUAN}

Konstitusi menjadi diskursus elemen bangsa yang merasa punya tanggung jawab menjaga keberlanjutan hidup bangsanya, yang diskursus ini tidak akan pernah mengenal titik nadir seiring dengan problem ketatanegaraan yang semakin bermacam-macam dari waktu ke waktu (Muflihurrahman, 2012:4).

Konstitusi memuat suatu aturan pokok yang fundamental mengenai sendi-sendi pertama untuk menegakkan suatu bangunan besar yang disebut negara. Sendi-sendi itu tentunya harus kokoh, kuat dan tidak mudah runtuh agar bangunan negara tetap tegak berdiri. Ada dua macam konstitusi di dunia, yaitu konstitusi tertulis (written constitution) dan konstitusi tidak tertulis (unwritten constitution), Konsititusi ini seringkali dipahami sebagai hukum tertulis (geschreven recht) yang termuat dalam undang-undang dan hukum tidak tertulis (ongeschreven recht) yang berwujud dalam adat kebiasaan. Amos J. Peaslee menyatakan hampir semua negara di dunia mempunyai konstitusi tertulis, kecuali Inggris dan Kanada. 
Konstitusi Indonesia Undang-Undang Dasar 1945 (selanjutnya disebut UUD 1945) yang berbentuk tertulis, ternyata tidak berharga mati untuk diperbarui. Terbukti, sudah beberapa kali dilakukan amandemen terhadap beberapa pasal yang dinilai tidak sejalan dengan nilai-nilai demokrasi, dan perkembangan masyarakat.

Sudah beberapa kali dilakukan amandemen terhadap UUD 1945, ini berarti tidak lantas konstitusi menjadi kitab suci yang tidak boleh diamandemen. Kelompok yang menghendaki amandemen konstitusi mengidealitaskan supaya dilakukan amandemen lanjutan. Amandemen konstitusi secara berkelanjutan tidak ada kaitannya dengan munculnya asumsi kalau konstitusi mengidap labilitas, tetapi hal ini berkaitan dengan kepentingan kesejatian demokrasi.

Menurut pendapat Husnie Thamrien, ada beberapa tujuan amandemen konstitusi, pertama, untuk menyempurnakan aturan dasar mengenai tatanan negara agar dapat lebih mantap dalam mencapai tujuan nasional serta menyempurnakan aturan dasar mengenai jaminan dan pelaksanaan kekuatan rakyat; kedua, memperluas partisipasi rakyat agar sesuai dengan perkembangan paham demokrasi; ketiga, menyempurnakan aturan dasar mengenai jaminan dan perlindungan hak agar sesuai dengan perkembangan HAM dan peradaban umat manusia yang menjadi syarat negara hukum; keempat, menyempurnakan aturan dasar penyelenggaraan negara secara demokratis dan modern melalui pembagian kekuasan secara tegas sistem check and balances yang lebih ketat dan transparan dan pembentukan lembagalembaga negara yang baru untuk mengakomodasi perkembangan kebutuhan bangsa dan tantangan jaman; kelima, menyempurnakan aturan dasar mengenai jaminan konstitusional dan kewajiban negara memwujudkan kesejahteraan sosial mencerdaskan kehidupan bangsa, menegakkan etika dan moral serta solidaritas dalam kehidupan bermasyarakat berbangsa dan bernegara sesuai dengan harkat dan martabat kemanusiaan dalam perjuangan mewujudkan negara kesejahteraan; dan keenam, melengkapi aturan dasar dalam penyelenggaraan negara yang sangat penting bagi eksistensi negara dan perjuangan negara mewujudkan demokrasi, menyempurnakan aturan dasar mengenai kehidupan bernegara dan berbangsa sesuai dengan perkembangan aspirasi kebutuhan dan kepentingan bangsa dan negara Indonesia ini sekaligus mengakomodasi kecenderungannya untuk kurun waktu yang akan datang (http://rippleworld.wordpress.com/ 2010/03/18/tujuan-amandemen-uud-1945)

Guillermo O'Donnel berpendapat, bahwa reformasi konstitusi yang terjadi sejalan dengan pergolakan politik akibat transisi dari pemerintahan otoriter, sarat benturan kepentingan politik antara kelompok status quo, yang masih membawa dan mempertahankan semangat otoriter, dengan kelompok reformis yang berusaha menuju ke negara demokratis (Denny Indrayana, http://els.bappenas.go.id/upload/ other/Urgensi\%20Komisi\%20Konstitusi.htm). Disisi lain, supremasi konstitusi telah menjadi ciri yang menonjol dari negara yang menganut paham demokrasi modern, karena konstitusi merupakan kontrak sosial (social contract) baru yang memuat norma-norma HAM dan demokrasi sebagai wujud dari kemauan seluruh rakyat untuk melepaskan diri dari belenggu rezim lama otoritarian dan sepakat untuk membangun pemerintahan baru berdasarkan ketentuan-ketentuan yang dituangkan dalam konstitusi (Benny K. Harman, http://eprints.ums.ac.id/321/1/5_WINAHYU.pdf). Bagaimana jika konstitusi yang diidealitaskan ini ternyata belum benar-benar mendukung pelaksanaan demokrasi.

Salah satu norma dalam konstitusi yang menjadi diskursus publik adalah soal impeachment. Dari sudut mekanisme atau sistem impeachment, konstitusi memang sudah mengaturnya, akan tetapi regulasi yang digariskan konstitusi ini dinilai masih bersifat general dan bahkan dianggap oleh sebagian pakar konstitusi dan peneliti konstitusi sebagai duri bagi terwujudnya demokrasi di negeri ini.

Dalam konstitusi sudah digariskan, bahwa impeachment bukan hanya menjadi wilayah politik, tetapi juga wilayahnya hukum. Ada sistem peradilan impeachment yang sudah pernah terwujud di Indonesia, khususnya di era sebelum konstitusi di amandemen. Sekarang paska amandemen konstitusi, sistem peradilan impeachment dinilai sebagian pakar dan peneliti konstitusi sebagai "jalur di atas kertas" atau mustahil bisa terwujud. Hasyim Ridwan (2011:91) menyebut, bahwa Mahkamah Konstitusi (selanjutnya disingkat MK) merupakan bukti historis era paska amandemen yang mempunyai tempat sakral dalam peradilan impeachment.

\section{PERUMUSAN MASALAH}

Berdasarkan latar belakang tersebut, dirumuskan permasalahan dalam penulisan, yakni bagaimanakah 
eksistensi peran MK dalam konstruksi sistem peradilan impeachment.

\section{METODE PENELITIAN}

Berpijak pada permasalahan tersebut, jenis penelitian yang dipilih adalah penelitian deskriptif, suatu penelitian yang dimaksudkan untuk memberikan dan menggambarkan data yang seteliti mungkin tentang manusia, keadaan atau gejala-gejala lainnya. Penelitian ini diharapkan dapat mendeskripsikan tentang peran MK dalam konstruksi sistem peradilan impeachment di Indonesia.

Penelitian ini menggunakan pendekatan yang bersifat yuridis normatif. Penelitian hukum dengan pendekatan yuridis normatif ini dilakukan dengan cara meneliti bahan pustaka atau data primer (Soerjono Soekanto dan Sri Mamudji, 2003:13-14) Penelitian ini sebatas mengkaji dari literatur atau bahan hukum tentang peran MK dalam konstruksi sistem peradilan impeachment di Indonesia.

Penelitian hukum yang menggunakan pendekatan yuridis normatif dilakukan dengan menggunakan data yang diperoleh dari studi pustaka. Berdasarkan hal ini, maka dalam menganalisis data yang diperoleh, penulis menggunakan teknik analisis isi (content analysis), yaitu suatu analisis terhadap isi data yang diperoleh.

\section{PEMBAHASAN}

\section{Sistem Peradilan dalam Amandemen Konstitusi}

Sebelum mengenal sistem peradilan, perlu dipahami dulu pengertian sistem. Sistem adalah suatu kebulatan atau keseluruhan yang kompleks atau terorganisir; suatu himpunan atau perpaduan hal-hal atau bagian-bagian yang membentuk suatu kebulatan atau keseluruhan yang kompleks atau utuh. Campbell menyatakan bahwa sistem adalah himpunan komponen atau bagian yang saling berkaitan yang bersama-sama berfungsi untuk mencapai sesuatu tujuan. Elias M. Awad menyebutkan, bahwa sistem adalah himpunan komponen atau sub sistem yang terogranisasikan dan berkaitan sesuai dengan rencana untuk mencapai sesuatu tujuan tertantu. Akhirnya Shrode dan Voich menyimpulkan, bahwa berdasarkan definisi-defenisi tentang sistem yang ada, maka unsurunsur suatu sistem adalah: himpunan bagian-bagian; bagian-bagian itu saling berkaitan; masing-masing bagian bekerja secara mandiri dan bersama-sama, satu sama lain saling mendukung; semuanya ditujukan pada pencapaian tujuan bersama atau tujuan sistem; dan terjadi di dalam lingkungan yang rumit atau kompleks (Tatang M. Amirin, 1996:10-11). Dengan demikian sistem, merupakan satu kesatuan yang utuh dan bulat yang terdiri dari sub-sub sistem, yang saling kait-mengkait dan apabila terjadi kontradiksi, maka sistem itu sendiri yang akan menyelesaikan. Salah satu jenis sistem yang diakui di tengah masyarakat adalah sistem hukum.

Sistem hukum merupakan bagian dari sistem sosial suatu masyarakat. Bila dilihat sebagai sistem tersendiri, maka menurut Lawrence M. Friedman, sistem hukum terdiri dari substansi hukum, struktur hukum, dan budaya hukum (legal culture) (Ali Aspandi, 2002:23). Sistem hukum ini diantaranya dapat terbaca secara lebih khusus pada sistem peradilan yang berlaku di Indonesia.

Ada yang menyebut, bahwa sistem peradilan nasional adalah suatu keseluruhan komponen peradilan nasional, pihak pihak dalam proses peradilan, hirarki kelembagaan peradilan maupun aspek-aspek yang bersifat prosedural yang saling berkait sedemikian rupa, sehingga terwujud suatu keadilan hukum. Tujuannya, yaitu mewujudkan keadilan hukum bilamana komponen-komponen sistemnya berfungsi dengan baik. Komponen komponen itu antara lain: materi hukum materil dan hukum acara (hukum formil). Guna mencapai tujuan ini, berbagai penyesuaian atau perubahan juga dilakukan, baik dalam ranah konstitusi maupun produk yuridis lainnya (seperti UU).

Pasal 24 Ayat (2) UUD 1945 mengamanatkan, bahwa kekuasaan kehakiman tidak hanya dilakukan oleh sebuah Mahkamah Agung (selanjutnya disingkat MA) tetapi juga oleh sebuah MK. Bahkan bagi seorang hakim, Pasal 24A ayat (2) UUD 1945 secara eksplisit menentukan, Hakim Agung harus memiliki integritas dan kepribadian yang tidak tercela, adil, profesional, dan berpengalaman di bidang hukum. Khusus untuk menjaga kemandirian dan integritas hakim, amandemen UUD 1945 juga memunculkan sebuah lembaga baru, yaitu Komisi Yudisial (selanjutnya disingkat KY) (http: //www.negarahukum.com/hukum/sistem-peradilanpasca-perubahan-uud-1945.html). Khusus MK, Jimly Asshiddiqie berpendapat bahwa MK Republik Indonesia adalah lembaga tinggi negara yang baru yang sederajat dan sama tinggi kedudukannya dengan MA.

Selama tahun 2003-2004 telah dilakukan serangkaian penyesuaian (perubahan dan pembentukan beberapa undang-undang) yang meliputi: pertama, 
Undang-Undang Nomor 24 Tahun 2003 tentang Mahkamah Konstitusi (Undang-undang Mahkamah Konstitusi ini sudah diamandemen dengan UndangUndang Nomor 8 tahun 2011 tentang Perubahan atas Undang-undang Nomor 24 Tahun 2003 tentang Mahkamah Konstitusi), kedua, Undang-Undang Nomor 4 Tahun 2004 tentang Kekuasaan Kehakiman (UU No. 4 Tahun 2004), ketiga, Undang-Undang Nomor 5 Tahun 2005 tentang Mahkamah Agung (UU No. 5 Tahun 2004), keempat, Undang-Undang Nomor 8 Tahun 2004 tentang Peradilan Umum (UU No. 8 Tahun 2004), kelima, Undang-Undang Nomor 9 Tahun 2004 tentang Peradilan Tata Usaha Negara (UU No. 9 tahun 2004), dan keenam, Undang-Undang Nomor 22 Tahun 2004 tentang Komisi Yudisial (UU No. 22 Tahun 2004). Selain UU MK, ada beberapa produk yuridis lainnya yang sudah dilakukan amandemen.

Kehadiran MK dalam konstruksi sistem peradilan itu menjadi wujud dinamika dan progresifitas dunia peradilan di Indonesia. MK dibentuk oleh negara untuk mengisi celah kekurangan dan stagnasi, sehingga aspirasi pencari keadilan (justiabelen) bisa dijembatani, meski tidak semua problem yang oleh publik sudah dinilai sebagai problem yuridis, belum sampai ditangani oleh MK.

Kehadiran MK itu juga menegaskan, bahwa Republik Indonesia membangun, mempertahankan, dan menguatkan negeri ini dengan memposisikan supremasi konstitusi, sehingga ketika sistem peradilan ikut diamandemen, yang orientasi amandemennya demi membahas kepentingan kedaulatan rakyat dan hak asasi manusia, maka ini menjadi perwujudan Indonesia sebagai negara yang mengandalkan supremasi konstitusi.

Benny K. Harman (Kompas, Juli 2003, http:// eprints.ums.ac.id/321/1/5._WINAHYU.pdf) menyebut, bahwa supremasi konstitusi telah menjadi ciri yang menonjol dari negara yang menganut paham demokrasi modern, karena konstitusi merupakan kontrak sosial (social contract) baru yang memuat norma-norma HAM dan demokrasi sebagai wujud dari kemauan seluruh rakyat untuk melepaskan diri dari belenggu rezim lama otoritarian dan sepakat untuk membangun pemerintahan baru berdasarkan ketentuan-ketentuan yang dituangkan dalam konstitusi.

Menurut Hegel The constitution is rational (vernuenftig) in as much as the state differentiates its operation (Wirksamkeit) according to the nature of the concept and like wise determines it. This works as follows; each of the powers is a totality in it self, because it contains the other powers (momente) as effective in it self, yet at the same time they remain part of the state's ideal form by expressing differences of its concept and still constitute only one ideal whole. Konstitusi yang baik tidak hanya didasarkan atas kemauan penguasa, akan tetapi didasari atas pemikiran yang rasional dan ideal tentang sebuah tujuan negara dan disepakati oleh semua masyarakat (Indonesia Law Reform, http://litigasi.blogspot.com/ 2008/03/urgensi-amandemen-uud-1945-jurnal.html). Keinginan masyarakat ini karakternya bermacammacam dan berkembang, sehingga konsekuensi logisnya konstitusinya pun mengalami perubahan. Perubahan ini berdampak pada jati diri suatu negara yang didasarkan atas hukum.

Berdasarkan prinsip negara hukum, sesungguhnya yang memerintah adalah hukum, bukan manusia. Hukum dimaknai sebagai kesatuan hirarkis tatanan norma hukum yang berpuncak pada konstitusi. Hal ini berarti, bahwa dalam sebuah negara hukum menghendaki adanya supremasi konstitusi. Supremasi konstitusi disamping merupakan konsekuensi dari konsep negara hukum, sekaligus merupakan pelaksanaan demokrasi karena konstitusi adalah wujud perjanjian sosial tertinggi. Oleh karena itu, aturan-aturan dasar konstitusional harus menjadi dasar dan dilaksanakan melalui peraturan perundang-undangan yang mengatur penyelenggaraan negara dan kehidupan masyarakat (Janedjri M. Gaffar, Supremasi Konstitusi, Uni Sosial Demokrat, http:// unisosdem.org/article_detail.php?aid).

Dari beberapa kali konstitusi di amandemen, terdapat banyak perubahan mendasar yang berhubungan dengan produk legislatif dan aspek-aspek, seperti perlindungan hak asasi manusia dan demokratisasi. Perubahan-perubahan fundamental ini harus sangat hati-hati dan penuh bijak, karena salah mengambil tindakan akan berakibat kerusakan bangsa dan negara. Amandemen seharusnya tidak mengubah UUD 1945-nya, tetapi mengadindum. Perubahan tidak akan banyak memberikan pengaruh besar dalam kehidupan kemasyarakatan dan kenegaraan, bilamana tidak diimplementasikan secara benar, konsekuen, dan maksimal.

Implementasi tersebut membuktikan eksistensi supremasi konstitusi secara empirik. Konstitusi tidak merupakan produk pajangan, jika penerapannya benar-benar dirasakan oleh masyarakat. Penerapan supremasi konstitusi ini menjadi semakin bermakna dan 
berkembang di tengah masyarakat, bilamana institusi seperti MK yang mendapatkan tugas mengawalnya juga berlanjut terus dan mampu menjalankan perannya secara benar dan progresif (Abdul Wahid, 2011:65)

Peran yang dijalankan oleh MK tersebut, menjadi parameter penghormatan secara istitusionalnya terhadap supremasi konstitusi. Konstitusi menjadi lebih tampak dalam realitas kebernyawaan atau berguna bagi pencari keadilan atau masyarakat seiring dengan tingkat kinerja MK, khususnya dalam menjatuhkan putusan-putusan yang berbasis keadilan substantif. Putusan MK ini berpangkal pada kewenangannya yang digariskan oleh konstitusi.

\section{Peradilan Impeachment}

Sebelum membahas kewenangan MK dalam kaitannya dengan Impeachment, perlu dipahami lebih dulu tentang kesejatian impeachment.

Istilah impeachment berasal dari kata to impeach, yang berarti meminta pertanggungjawaban. Jika tuntutannya terbukti, maka hukumannya adalah removal from office, atau pemberhentian dari jabatan. Dengan kata lain, kata impeachment itu sendiri bukanlah pemberhentian, tetapi baru bersifat penuntutan atas dasar pelanggaran hukum yang dilakukan. Oleh karena itu, dikatakan Charles L. Black, Strictly speaking, 'impeachment' means 'accusating' or 'charge'. Artinya, kata impeachment itu dalam bahasa Indonesia dapat dialihbahasakan sebagai dakwaan atau tuduhan (Jimly Asshiddiqie, 2007:600).

Secara harfiah dalam Kamus Besar Bahasa Indonesia Edisi Online, pemakzulan berasal dari kata makzul yang artinya berhenti memegang jabatan, turun takhta. Jadi pemakzulan artinya sebuah proses untuk menurunkan pejabat dari jabatannya. Dalam pengertian yang lebih populer sekarang ini, pemakzulan adalah adalah sebuah proses di mana sebuah badan legislatif secara resmi menjatuhkan dakwaan terhadap seorang pejabat tinggi negara. Pemakzulan bukan selalu berarti pemecatan atau pelepasan jabatan, namun hanya merupakan pernyataan dakwaan secara resmi, mirip pendakwaan dalam kasus-kasus kriminal, sehingga hanya merupakan langkah pertama menuju kemungkinan pemecatan. Saat pejabat tersebut telah dimakzulkan, ia harus menghadapi kemungkinan dinyatakan bersalah melalui sebuah pemungutan suara legislatif, yang kemudian menyebabkan pemecatan sang pejabat. Pemakzulan berlaku di bawah undang-undang konstitusi di banyak negara di dunia, termasuk Amerika Serikat, Brasil, Rusia, Filipina, dan Republik Irlandia.

Banyak pihak-pihak yang memahami, bahwa impeachment merupakan turunnya, berhentinya atau dipecatnya Presiden atau pejabat tinggi dari jabatannya. Sesungguhnya arti impeachment sendiri merupakan tuduhan atau dakwaan sehingga impeachment lebih menitikberatkan pada prosesnya dan tidak mesti berakhir dengan berhenti atau turunnya Presiden atau pejabat tinggi negara lain dari jabatannya (Harjono, http:// id.wikisource.org/wiki/Mekanisme_Impeachment_ $\% 26 \_$hukum_Acara)

Menurut Marsilam Simanjuntak, impeachment adalah suatu proses tuntutan hukum (pidana) khusus terhadap seorang pejabat publik ke depan sebuah quasi pengadilan politik, karena ada tuduhan pelanggaran hukum sebagaimana yang ditentukan UUD. Hasil akhir dari mekanisme impeachment ini adalah pemberhentian dari jabatan, dengan tidak menutup kemungkinan melanjutkan proses tuntutan pidana biasa bagi kesalahannya sesudah turun dari jabatannya (Eldo Denara, Mengenal Impeachment di Indonesia, http: //matahatifh. wordpress.com/2010/01/24/mengenalimpeachment-di-indonesia-oleh-eldo-denara/)

Melihat dari contoh yang telah terjadi, maka haruslah dibedakan antara perkataan impeachment dengan removal from office yang berarti pemberhentian dari jabatan. Seperti dikatakan oleh Jethro K. Lieberman, impeachment is the means by which the federal officials may be removed from office for misbehavior. Lembaga impeachment ini hanyalah sarana untuk melakukan pemberhentian terhadap pejabat publik. Namun hasilnya masih tergantung pada proses hukum dan politik yang melingkupinya.

Banyak pihak-pihak yang memahami, bahwa impeachment merupakan turunnya, berhentinya atau dipecatnya Presiden atau pejabat tinggi dari jabatannya. Sesungguhnya arti impeachment sendiri merupakan tuduhan atau dakwaan sehingga impeachment lebih menitikberatkan pada prosesnya dan tidak mesti berakhir dengan berhenti atau turunnya Presiden atau pejabat tinggi negara lain dari jabatannya (Harjono, http:// id.wikisource.org/wiki/Mekanisme_Impeachment_ $\% 26$ hukum Acara).

Impeachment berarti suatu proses pendakwaan atas perbuatan menyimpang dari pejabat publik. Pengertian demikian seringkali kurang dipahami, sehingga seolah-olah lembaga impeachment itu identik 
dengan 'pemberhentian'. Padahal proses permintaan pertanggungjawaban yang disebut impeachment itu tidak selalu berakhir dengan tindakan pemberhentian terhadap pejabat yang dimintai pertanggungjawaban. Contoh kasus adalah peristiwa yang dialami oleh mantan Presiden Amerika Serikat, Bill Clinton, yang diimpeach oleh House of Representatives, tetapi dalam persidangan Senat tidak dicapai jumlah suara yang diperlukan, sehingga kasus Bill Clinton tidak berakhir dengan pemberhentian (Eldo Denara, Mengenal Impeachment di Indonesia, http://matahatifh. wordpress.com/2010/01/24/mengenal-impeachmentdi-indonesia-oleh-eldo-denara).

Black's Law Dictionary mendefinisikan arti kata impeachment sebagai A criminal proceeding against a public officer, before a quasi political court, instituted by a written accusation called 'articles of impeachment". For example a written accusation by the house of representatives of the United States to the Senate of the United States, against the President, Vice President, or an officer of the United States (Henry Campbell Black, 1991:516) Impeachment diartikan sebagai suatu proses peradilan pidana terhadap seorang pejabat publik yang dilaksanakan di hadapan Senat, disebut dengan quasi political court. Suatu proses impeachment dimulai dengan adanya articles of impeachment, yang berfungsi sama dengan surat dakwaan dari suatu peradilan pidana. Jadi, artikel impeachment adalah satu surat resmi yang berisi tuduhan yang menyebabkan dimulainya suatu proses impeachment.

Menurut Webster's New World Dictionary, istilah to impeach, berarti, to bring (a public official) before the proper tribunal on the charges of wrongdoing. Sementara itu, Encyclopedia Britanica menjelaskan pengertian impeachment sebagai, a criminal proceeding instituted against a public official by a legislative body.

Menurut Indrayana, impeachment adalah proses pemberhentian yang dilakukan oleh parlemen. Dalam istilah kuno sejak jaman Mesir Kuno dengan istilah Iesangelia sejak abad ke 17 adalah dakwaan atau tuntutan. Istilah tersebut diadopsi pemerintah Inggris dan dimasukan dalam kontitusi Amerika Serikat akhir abad 18. Pengertian impeachment merupakan istilah yang umum dipakai dalam hukum tatanegara untuk menyebut proses pendakwaan, dan sama atau sebanding dengan istilah dakwaan dalam proses peradilan pidana. Namun demikian dalam proses impeachment adalah berkaitan dengan peradilan hukum tata negara yang artinya peradilan akan memutuskan apakah terdakwa diberhentikan atau sanksi lain berupa larangan menduduki jabatan. Penerapan akan pengertian impeachment ini di Amerika menjadi perdebatan bahwa high crimes and misdemeanors mempunyai pengertian luas atau general. ${ }^{23}$ (http: //armingsh.blogspot.com/2010/08/istilah-istilahimpeachment.html, diunduh 5 April 2013)

Encyclopedia Britanica menguraikan pengertian impeachment sebagai a criminal proceeding instituted against a public official by a legislative body. Dengan demikian nyatalah bahwa impeachment berarti proses pendakwaan atas perbuatan menyimpang dari pejabat publik. Pengertian demikian seringkali kurang dipahami, sehingga seolah-olah lembaga impeachment itu identik dengan pemberhentian. Padahal, proses permintaan pertanggungjawaban yang disebut impeachment itu tidak selalu berakhir dengan tindakan pemberhentian terhadap pejabat yang dimintai pertanggungjawaban (http://www.mahkamahkonstitusi.go.id?File\%20Pub likasi/KI_Impeachment.pdf).

Objek dari tuduhan impeachment tidak hanya terbatas pada pemimpin negara, seperti Presiden atau Perdana Menteri, namun juga pada pejabat tinggi negara. Objek dari impeachment di berbagai negara berbeda-beda dan terkadang memasukkan pejabat tinggi negara seperti hakim atau ketua serta para anggota lembaga negara menjadi objek impeachment. Namun objek impeachment yang menyangkut pimpinan negara akan lebih banyak menyedot perhatian publik. Seiring dengan Perubahan UUD 1945, Indonesia juga mengadopsi mekanisme impeachment yang objeknya hanya menyangkut pada Presiden dan/atau Wakil Presiden (Harjono, http://id.wikisource.org/wiki/ Mekanisme_Impeachment_\%26_hukum_Acara).

Semua konstitusi negara modern mengenal mekanisme dari pemberhentian atau penggantian pemimpinnya di tengah jalan. Yang berbeda hanya jenis pelanggaran hukum yang dijadikan alasan untuk pendakwaan. Pelanggaran hukum yang dijadikan alasan itu ada yang bersifat pidana dan ada juga yang bersifat tata negara. Konstitusi Amerika Serikat Pasal 2 ayat (4) treason, bribery or other high crimes, and misdemeanors, Konstitusi Argentina Pasal 52 malfeasance or crime committed in exercise of their offices or for common crimes, Konstitusi Perancis Pasal 68 only the case of high treason, dan Konstitusi Rusia Pasal 93 ayat (1) treason or the commission 
of some other grave crime, misalnya mengaitkannya dengan pelanggaran hukum pidana. Tetapi Konstitusi Jerman, Pasal 61 ayat (1) mengaitkan impeachment itu, baik dengan pelanggaran tata negara maupun pidana, dan bahkan dengan semua bidang hukum: The Bundestag or the Bundesrat may impeach the Federal President before the Federal Constitutional Court for wilful violation of this Basic Law or any other federal statute. Presiden dapat diimpeach, baik karena didakwa melanggar UUD ataupun UU Federal lainnya. (Mohammad Ali Syafaat, http://safaat.lecture.ub.ac.id/ files/2011/11/Bab-IX-Impeachment.pdf).

Khusus di Indonesia, Mohammad Ali Syafaat (http://safaat.lecture.ub.ac.id/files/2011/11/Bab-IXImpeachment.pdf) memandang berbeda, bahwa adanya ketentuan tentang pemberhentian Presiden dan/atau Wakil Presiden dalam masa jabatannya dalam UUD 1945 pasca perubahan tersebut memunculkan istilah baru dalam bidang hukum tata negara, yaitu impeachment dan pemakzulan. Pemakzulan merupakan proses pemberhentian seorang pejabat publik dalam masa jabatannya, atau sebelum masa jabatan tersebut berakhir atau disebut dengan istilah removal from office. Dalam proses pemakzulan tersebut terdapat mekanisme impeachment, yaitu pendakwaan atas suatu perbuatan tertentu yang dapat menjadi alasan pemberhentian.

Dalam praktek impeachment yang pernah dilakukan di berbagai negara, hanya ada beberapa proses impeachment yang berakhir dengan berhentinya seorang pimpinan negara. Salah satunya adalah Presiden Lithuania, Rolandas Paskas, dimana proses impeachment itu berakhir pada berhentinya Paskas pada tanggal 6 April 2004. Di Amerika pernah terjadi beberapa kali proses impeachment terhadap Presiden misalnya pada Andrew Johnson, Richard Nixon, dan terakhir pada William Clinton. Namun, ke semua tuduhan impeachment yang dilakukan di Amerika itu tidak berakhir pada berhentinya Presiden. Pada kasus Richard Nixon, Nixon mengundurkan diri pada saat proses impeachment berlangsung sehingga belum sampai pada putusan dari proses impeachment itu.

Sebagai contoh lagi, Presiden Amerika Serikat Bill Cinton diimpeach oleh House of Representative, tetapi dalam persidangan Senat tidak dicapai jumlah suara yang diperlukan, sehingga kasus Bill Clinton tidak berakhir dengan pemberhentian. Karena itu, harus dibedakan antara perkataan impeachment dengan removal from office yang berarti pemberhentian dari jabatan. Seperti dikatakan oleh Jethro K. Lieberman, Impeachment is the means by which the federal officials may be removed from office for misbehavior. Lembaga impeachment ini hanyalah sarana untuk memungkinkan dilakukannya pemberhentian terhadap pejabat publik, tetapi hasilnya tergantung proses pembuktian hukum dan proses politik yang menentukan kemungkinan dilakukan atau tidaknya pemberhentian itu (Abdul Rasyid Thalib, 2006:463)

Objek dari impeachment di berbagai negara berbeda-beda dan terkadang memasukkan pejabat tinggi negara seperti hakim atau ketua serta para anggota lembaga negara menjadi objek impeachment. Namun objek impeachment yang menyangkut pimpinan negara akan lebih banyak menyedot perhatian publik. Seiring dengan Perubahan UUD 1945, Indonesia juga mengadopsi mekanisme impeachment yang objeknya hanya menyangkut pada Presiden dan/atau Wakil Presiden.

Jimly Asshdhiqy menyebut, bahwa alasanalasan impeachment pada masing-masing negara juga berbeda-beda. Selain itu, perdebatan mengenai penafsiran dari alasan impeachment juga mewarnai proses impeachment atau menjadi wacana eksplorasi pengembangan teori dari sisi akademis. Contohnya adalah batasan dari alasan misdeamenor dan high crime yang dapat digunakan sebagai dasar impeachment di Amerika Serikat. Di Indonesia, kedua alasan tersebut diadopsi dan diterjemahkan dengan perbuatan tercela dan tindak pidana berat lainnya. Batasan dari misdemeanor dan high crime di Amerika sendiri masih menjadi perdebatan. Sedangkan definisi atas alasan impeachment tersebut di Indonesia dijabarkan dalam Pasal 10 ayat (3) UU MK. Yang disebut tindak pidana berat lainnya adalah tindak pidana yang diancam dengan pidana penjara 5 (lima) tahun atau lebih. Sedangkan perbuatan tercela adalah perbuatan yang dapat merendahkan martabat Presiden dan/atau Wakil Presiden. Meski telah disebutkan dan coba didefinisikan dalam ketentuan peraturan perundangundangan, kedua alasan impeachment tersebut masih memancing perdebatan wacana secara akademis yang dapat digali lebih dalam lagi.

\section{Posisi Fundamental Mahkamah Konstitusi}

Pasal 24C ayat (1) UUD 1945 memang sudah memberikan empat wewenang kepada Mahkamah Konstitusi, yaitu: Memutus pengujian undang-undang terhadap Undang-Undang Dasar; Memutus sengketa 
kewenangan lembaga negara yang kewenangannya diberikan oleh Undang-Undang Dasar; Memutus pembubaran partai politik; dan Memutus perselisihan hasil Pemilu.

Selain itu, berdasar Pasal 24C ayat (2) UUD 1945 memberikan kewajiban kepada MK untuk memberikan putusan atas pendapat DPR mengenai dugaan pelanggaran hukum oleh Presiden dan Wakil Presiden sebagai tahapan yang harus dilalui untuk pemakzulan Presiden dan/atau Wakil Presiden.

Paska amandemen konstitusi, (hasil amandemen keempat UUD 1945. yang digariskan dalam Pasal 7A, Pasal 7B serta Pasal 24C ayat (2). Pemberhentian diatur secara khusus untuk Presiden dan/atau Wakil Presiden dengan istilah dapat diberhentikan dalam masa jabatannya), mekanisme impeachment di Indonesia harus melalui 3 (tiga) tahap pada 3 (tiga) lembaga tinggi negara yang berbeda. Tahapan pertama proses impeachment adalah pada DPR. DPR dalam menjalankan fungsi pengawasannya memiliki tugas dan kewenangan untuk mengawasi jalannya pemerintahan. Bilamana dalam pelaksanaan tugas dan kewenangan tersebut DPR menemukan bahwa Presiden dan/atau Wakil Presiden telah melakukan pelanggaran-pelanggaran yang termasuk dalam alasan impeachment sebagaimana disebutkan dalam pasal 7A UUD 1945, maka DPR setelah sesuai dengan ketentuan prosedur internalnya (Tata Tertib DPR) mengajukan tuntutan impeachment tersebut kepada MK.

Tahapan kedua proses impeachment berada di tangan MK. Sesuai dengan ketentuan pasal 7B ayat (4) maka MK wajib memeriksa, mengadili dan memutus pendapat DPR tersebut. Kedudukan DPR dalam persidangan MK adalah sebagai pihak pemohon karena DPR-lah yang memiliki inisiatif dan berpendapat bahwa Presiden dan/atau Wakil Presiden telah melakukan pelanggaran yang disebutkan dalam Pasal 7A UUD 1945.

Setelah MK memberi putusan atas pendapat DPR dan isi putusan MK adalah membenarkan pendapat DPR tersebut maka tahapan ketiga proses impeachment berada di MPR. UUD 1945 memberikan batasan bahwa hanya bilamana MK membenarkan pendapat DPR tersebut maka DPR dapat meneruskan proses impeachment atau usulan pemberhentian ini kepada MPR. Keputusan DPR untuk melanjutkan proses impeachment dari MK ke MPR juga harus melalui keputusan yang diambil dalam Sidang Paripurna DPR.
Proses pengambilan keputusan MPR atas usul pemberhentian Presiden dan/atau Wakil Presiden ini dilakukan dengan mengambil suara terbanyak dalam rapat paripurna. Komposisi dan tata cara pengambilan suara terbanyak itu juga diatur secara rinci oleh UUD 1945 yaitu rapat paripurna MPR harus dihadiri oleh sekurang-kurangnya 3/4 dari seluruh anggota MPR. Persetujuan atas usul pemberhentian Presiden dan/ atau Wakil Presiden harus disepakati oleh sekurangkurangnya 2/3 dari anggota MPR yang hadir dalam rapat paripurna.

Dengan kewenangan fundamental yang dimiliki MK itu, MK diidealitaskan dapat mengawal nilainilai konstitusi dan demokrasi, sehingga fungsi dan tugasnya seringkali diposisikan sebagai: pengawal konstitusi (the guardian of constitution); penafsir akhir konstitusi (the final interpreter of constitution); pengawal demokrasi (the guardian of democracy); pelindung hak-hak konstitusional warga negara (the protector of citizen's constitutional rights); dan pelindung hak-hak asasi manusia (the protector of human rights).

Pelanggaran hukum yang diduga dilakukan presiden yang disebut dalam Pasal 10 ayat (2) UU Nomor 24 Tahun 2003, telah diperjelas dalam ayat (3) dengan memberi batasan sebagai berikut: pertama, Penghianatan terhadap negara adala tindak pidana terhadap keamanan negara sebagaimana diatur dalam undang-undang; kedua, Korupsi dan penyuapan adalah tindak pidana korupsi atau penyuapan sebagaimana diatur dalam undang-undang; ketiga, Tindak pidana berat lainnya adalah tindak pidana yang diancam dengan pidana penjara 5 (lima) tahun atau lebih; keempat, Perbuatan tercela adalah perbuatan-perbuatan yang dapat merendahakan martabat Presiden dan/atau Wakil Presiden; kelima, Tidak lagi memenuhi syarat sebagai presiden dan/atau wakil presiden adalah syarat sebagaimana dtentukan dalam Pasal 6 UUD RI 1945.

Dari kewenangan yang disebutkan di atas terlihat bahwa sengketa yang diperkarakan dan diadili MK sangat banyak berkaitan dengan proses politik dan produk hukum, sebagian besar merupakan perselisihan yang syarat dengan sifat politik sebagai salah satu karakteristik sengketa. Perselisihan yang terfokus pada masalah politik ini membuat peran MK dihadapkan dengan tantangan yang tidak ringan, yang menguji integritas moral, intelektualitas, maupun independensinya. 
MK merupakan lembaga yudisial independen, yang mendapatkan kewenangan khusus. MK diberi tempat oleh konstitusi untuk menjalankan amanat sakral. Amanat ini telah terbukti mengangkat pamor MK, sehingga MK tidak ditempatkan oleh masyarakat sebagai institusi pelengkap penderita atau sekedar menemani lembaga-lembaga yudisial yang sedang carut-marut.

Pamor MK itu masih terbatas di tiga kewenangan, antara lain penyelesaian perselisihan Pemilukada, permohonan uji materi undang-undang (judicial review), serta sengketa antar lembaga negara. Sedangkan kewenangan MK yang belum teruji adalah pembubaran Parpol dan pemberian putusan atas pendapat DPR mengenai dugaan pelanggaran hukum oleh Presiden dan Wakil Presiden sebagai tahapan yang harus dilalui untuk pemakzulan Presiden dan/atau Wakil Presiden

Kewenangan di lini impeachment itu menjadi tidak jalan akibat tidak adanya permohonan atau permintaan pendapat dari DPR dugaan pelanggaran hukum oleh Presiden dan Wakil Presiden sebagai tahapan yang harus dilalui untuk pemakzulan Presiden dan/atau Wakil Presiden. Kalau DPR meminta pendapat kepada MK, barulah kewenangan MK menjadi teruji, apakah putusannya menyudutkan atau melemahkan posisi Presiden dan/atau Wakil Presiden ataukah justru memutuskan ketidakterlibatan Presiden dan/atau Wakil Presiden dalam perbuatan yang dituduhkan oleh DPR.

Sebelum ada MK atau pra konstitusi diamandemen, MPR telah memakzulkan dua Presiden RI, yakni Ir. Soekarno, berdasarkan TAP MPRS No. XXXIII/MPRS/ 1967 dan K.H. Abdurrahman Wahid, berdasarkan TAP MPR No. II/MPR/2001. Kasus pemakzulan kedua Presiden ini memang menunjukkan dan membenarkan kalau kedudukan Presiden bukanlah kedudukan yang kebal dari pertanggungjawaban yuridis ataupun politis. Presiden bisa saja dilengserkan atau dicopot dari jabatannya. Tidak ada yang kebal hukum di negara hukum ini. Siapapun orangnya, termasuk Presiden atau Wakil Presiden bisa dicopot dari jabatannya.

Selain itu, negara yang menganut paham demokrasi menghendaki bahwa setiap pemegang kekuasaan harus memperoleh mandat dan dapat diawasi oleh rakyat. Hal tersebut tidak terkecuali terhadap seorang Presiden. Sebagai pemegang kekuasaan eksekutif, Presiden memiliki kewajiban untuk mempertanggungjawabkan kekuasaannya tersebut kepada pemberi mandat.
Pertanggungjawaban merupakan suatu unsur yang melekat pada dengan jabatan Presiden, karena dalam negara yang menganut sistem demokrasi tidak ada kekuasaan tanpa pertanggungjawaban (Soewoto Mulyosudarmo, 1997:1-2)

Tidak sedikit yang menyebut, bahwa menjatuhkan presiden atau wakil presiden melalui proses impeachment sebagai jalan yuridis dan politik yang mustahil. Fidel Dakati Biawa (http://politik.kompasiana.com/2010/ 01/26/tanggungjawab-tanpa-impeachment) menyebut, bahwa pertanggungjawaban tidaklah identik dengan impeachment. Sebab kenyataannya setiap tahunnya Presiden membuat pidato pertanggungjawaban APBN, jadi tidak ada yang perlu dirisaukan dari sebuah pertanggungjawaban. Karena pertanggungjawaban belumlah tentu akhir dari segalanya. Bisa jadi malah menjadi lompatan besar menghadapi masalah, atau katakanlah ada temuan-temuan penyalahgunaan dana bail-out seperti dalam kasus Century, tentunya tidak berarti bahwa konsekuensinya adalah impeachment. Mungkin saja penyalahgunaan terhadap kewenangan tersebut tidak sepengetahuan Presiden, sehingga bisa ditindaklanjuti dengan mekanisme penegakan hukum yang biasa berlaku.

Sesungguhnya impeachment sangat sulit sekali dilaksanakan di Indonesia. Hal ini disebabkan dukungan parlemen yang kuat terhadap pemerintah. Sekarang ini, koalisi Partai Politik (Parpol) menjadi pendukung pemerintahan dan menguasai 60 persen kursi yang ada di DPR, sedangkan yang dimungkinkan oposisi hanya 40 persen. Sehingga, impeachment sulit sekali dilakukan mengingat kedudukan presiden yang sangat kuat di Indonesia. Mekanisme pemakzulan sendiri sudah diatur dalam konstitusi agar forum politik DPR tidak bisa serta merta menjatuhkan presiden. Sebagaimana presiden tidak bisa membubarkan DPR, DPR juga tidak bisa menjatuhkan presiden kecuali presiden terbukti melakukan pelanggaran hukum. Pembuktian dugaan pelanggaran hukum oleh Presiden dilakukan di MK. Jika MK menyatakan Presiden terbukti melakukan pelanggaran hukum, maka proses selanjutnya berlangsung di MPR untuk meminta pertanggungjawaban presiden. Jika presiden memang terbukti bersalah maka DPR sudah mempunyai bukti nyata untuk mengajukan permintaan tanggung jawab presiden lewat forum MPR.

Keterlibatan peran MK dalam problem tersebut tidak terlepas dari perubahan ketatanegaraan Indonesia yang digariskan dalam konstitusi. Masa peralihan 
Indonesia menuju suatu cita demokrasi merupakan salah satu proses yang menjadi tahapan penting perkembangan Indonesia. Salah satu aspek yang menjadi bagian dari proses peralihan Indonesia menuju cita demokrasi adalah terjadinya perubahan di bidang ketatanegaraan yang diantaranya mencakup proses perubahan konstitusi Indonesia Tahun 1945 (UUD 1945). UUD 1945 telah mengalami perubahan-perubahan mendasar sejak dari Perubahan Pertama pada tahun 1999 sampai ke Perubahan Keempat pada tahun 2002 (Jimly Asshiddiqie, http://legal.daily-thought.info). Perubahan mendasar ini sekaligus memberikan garis penegas, bahwa logika impeachment sudah mengalami pergeseran. Artinya logika yang digunakan untuk memakzulkan Gus Dur jauh lebih mudah dibandingkan sekarang. Logika yang digunakan dominan pada kolaborasi kepentingan dan kekuatan politik dengan cara gampang, sementara di masa sesudahnya, sudah ada mekanisme yang membuatnya mustahil bisa menjatuhkan presiden atau wakil presiden.

Setelah terjadinya empat kali perubahan UUD 1945 mengakibatkan beberapa perubahan antara lain adanya ketentuan yang secara eksplisit mengatur pemberhentian Presiden dan/atau Wakil Presiden dalam masa jabatannya oleh MPR atas usul DPR. Alasan pemberhentian Presiden dan/atau Wakil Presiden disebutkan secara limitatif dalam konstitusi, yaitu pengkhianatan terhadap negara, korupsi, penyuapan, tindak pidana berat lain, perbuatan tercela, atau tidak lagi memenuhi syarat sebagai Presiden dan/atau Wakil Presiden. Ketentuan tersebut diatur dalam Pasal 7A dan 7B Perubahan Ketiga UUD 1945 (MPR, 2002: 42-43).

Miftahul Huda menyebut, bahwa mengenai alasan pendakwaan (impeachment) di tiap negara menentukan berbeda-beda, yakni terdapat negara yang menerapkan hanya pelanggaran hukum yang bersifat pelanggaran pidana atau pelanggaran yang lebih bersifat tata negara yang menjadi dasar pendakwaan. Untuk pelanggaran pidana misalkan diatur dalam Konstitusi Amerika Serikat dengan alasan-alasan: treason, bribary or other high crimes and misdemeanor (Pasal 2 ayat (4)) dan Konstitusi Perancis dengan only the case of high treason (Pasal 68). Sedang Konstitusi Jerman mengaitkan tidak hanya pelanggaran pidana dan tata negara, tetapi juga pelanggaran-pelanggaran hukum lainnya yaitu The Bundestag or the Bundesrat may impeach the Federal President before the Federal Constitutional Court for wilful violation of this Basic
Law or any other federal statute. Presiden dapat diimpeach, baik karena didakwa melanggar UUD atau pun UU Federal lainnya (Miftahul Huda, http: //www.miftakhulhuda.com/2010/01/impeachment.html). Alasan ini juga masih menimbulkan perdebatan, karena alasan impeachment ini berkaitan dengan masalah mekanisme, yang di setiap negara tidak selalu sama, termasuk antara mekanisme sebelum dan sesudah amandemen konstitusi.

Perdebatan yang mengerucut pada mekanisme impeachment adalah mekanisme yang dinilai tidak memungkinkan mampu dipenuhi, karena banyaknya tahapan dan hadangan yang secara politik membuat presiden dan atau wakil presiden atau pihak-pihak lain yang dimintai pertanggungawaban tetap bisa menikmati kenyamanan, meski dalam kenyataan (selama menjalankan roda pemerintahan), presiden, wakil presiden, dan siapapun yang menjalankan roda pemerintahan, diduga atau minimal diasumsikan melakukan banyak pelanggaran hukum, khususnya kejahatan bermodus penyalahgunaan kekuasaan.

Kalau dikaitkan dengan teori atau logika kekuasaan, seharusnya sistem peradilan impeachment bukanlah sistem yang sekedar asal terumus secara tekstual dalam konstitusi, karena di Indonesia ini, berbagai bentuk kejahatan istimewa (exstra ordinary crime) yang pelakunya dari kalangan masyarakat pintar (intelek) dan punya kekuasaan mapan sangat marak terjadi di negara ini. Kasus Century dan Hambalang menjadi logika yuridis rasional dan obyektif untuk menjadikan sistem peradilan impeachment sebagai solusi strategisnya.

Selain itu, di tengah masyarakat, ada fenomena ledakan (booming) penyalahalamatan uang negara dimana-mana. Dari satu kasus korupsi yang muncul di satu tempat (institusi), diniscayakan di tempat lain korupsi juga terjadi. Hal ini berelasi dengan "ideologi" kekuasaan yang tidak terpisah dengan korupsi. Dimana ada kekuasaan, di situ ada "kreasi" korupsi, sekecil apapun korupsi itu "dikreasikan" dan bahkan diakselerasikan modus operandinya. Korupsi menjadi marak akibat dugaan koruptor di level elite atau di hirarkhis tertingginya tidak dipertanggungjawabkan secara inklusif, berkeadilan, dan egalitarian.

Klittgard menyatakan, bahwa korupsi timbul karena adanya monopoli kekuasaan ditambah diskresi (discretion) yang, tidak diimbangi dengan pertanggungjawaban (accountability). Rumus $\mathrm{C}=\mathrm{M}$ $+\mathrm{D}-\mathrm{A}$ ini menunjukkan bahwa discretion (otoritas) 
merupakan kewenangan yang melekat pada setiap orang atau elite untuk mengambil pilihan dari beberapa alternatif, yang dilakukan tanpa ada kendali akuntabilitas, sehingga menjadi sumber korupsi.

Logika Klittgard itu sejalan dengan pernyataan paling populer dari Lord Acton yang menyebut power tend to corrupt, absolute power corrupt absolutely atau kekuasaan itu cenderung melakukan korupsi dan semakin absolut kekuasaan, maka korupsi juga semakin absolut. Akibat absolutnya korupsi di negeri ini, kerugian besar dan berlapis sudah dirasakan oleh rakyat (Bambang Satriya, 2012:47).

Misalnya pada Januari 2012 diberitakan, bahwa Indonesia kehilangan Rp 2.13 trilliun (US\$238.6 million) akibat korupsi pada tahun 2011. Akibat besarnya kerugian negara dan dahsyatnya sepak terjang koruptor, Corruption Perceptions Index 2012 menempatkan Indonesia di peringkat 118 (Bambang Satriya, 2012:48).

Kondisi carut marut citra Indonesia akibat korupsi itu mengindikasikan kalau pelaku korupsi telah memperlakukan bangsa dan rakyat ini sekedar obyek jarahan, dan bukan negara atau bangsa yang bersih dan bermartabat. Kekayaan yang dimiliki rakyat dalam APBN bukan difungsikan untuk memanusiakan atau menyejahterakan rakyat, tetapi menyejahterakan individu, keluarga, kroni, dan partainya. Bahkan mereka terus berusaha jadikan kekuasaan di lini apapun diintervensi dan dihegemoni supaya kehilangan integritas moral, kecerdasan intelektualitas, dan kearifannya.

Komunitas koruptor itu bahkan menstigmatisasi kalau Indonesia masihlah negara yang "sekedar" berlandaskan hukum, karena dari sisi kenyataannya (das sein), mereka merasa berhasil memproduksi berbagai perilaku yang menunjukkan kalau Indoneia pantas diberi status sebagai state without law (negara tanpa hukum). Kalau julukannya demikian, berarti koruptor yang berasal dari okunm-oknum penguasa layak dikategorikan sebagai pelaku yang mempermainkan konstitusi dan mengkhianati rakyat, yang wajib dipertanggungjawabkan secara yuridis. Bentuk pertanggungjawaban ini diantaranya dapat melalui sistem peradilan impeachment.

Meskipun dalam sistem peradilan impeachment, posisi MK berada di tahapan kedua setelah DPR, namun posisi ini sangat strategis, karena MK menentukan atau mendapatkan amanat dari negara atau peraturan perundang-undangan untuk memberikan fatwa tentang kebersalahan tidaknya Presiden dan atau Wakil Presiden.
Kewenangan ini jelas tidak ringan bagi MK. Ada beban berat yang melekat dalam kewenangan MK yang berhubungan dengan karier politik Presiden dan atau Wakil Presiden.

Mekanisme impeachment, meski itu sudah digariskan dalam konstitusi dan didukung oleh peraturan perundang-undangan yang lain, seperti di dalam Undang-Undang No. 24 Tahun 2003 tentang MK, yang kemudian Undang-Undang MK ini juga diperbarui dengan Undang-Undang No. 8 Tahun 2011, tetap saja masih menimbulkan berbagai problematika di tengah kehidupan bermasyarakat dan bernegara. Beberapa gugatan publik yang terlontar diantaranya, mampukah mekanisme impeachment ini terlaksana, atau mampukan mekanisme impeachment ini menjadi sistem yang mencerminkan kedaulatan rakyat atau demokrasi di negara hukum ini.

Peran MK memang sudah dipertegas dalam tahapan impeachment sebagai jembatan dalam sistem peradilannya, akan tetapi sistem ini tetaplah disebut oleh masyarakat atau sebagian pakar hukum tata negara sebagai sistem yang sekedar ada dalam konstitusi, dan bukan sebagai sistem peradilan yang benar-benar bisa digunakan untuk mempertanggungjawabkan Presiden dan atau Wakil Presiden yang diduga melakukan pelanggaran atau kejahatan. MK yang berperan sebagai jembatan yang memberikan landasan hukum atas peristiwa politik impeachment itu diantaranya adalah MK dari Lithuania. MK Lithuania termasuk MK yang ikut memberhentikan Presidennya, Rolandas Paskas dalam proses impeachment.

Sistem ketatanegaraan di negeri ini secara langsung atau tidak langsung dapat memengaruhi peradilan impeachment. peradilan impeachment memang bisa dijalankan oleh MK, namun untuk membuatnya berjalan, ada sistem politik ketatanegaraan yang menjadikannya sebagai batu terjal untuk terwujud.

Faktor utama proses peradilan impeachment itu terletak di tangan dewan (DPR). Padahal, keberadaan DPR di ranah kekuasaan merupakan kepanjangan tangan parpol. Meski berkali-kali mencuat kritik keras bahwa ketika seseorang sudah jadi menteri, wakil presiden, hingga presiden, harus melepaskan diri dari 'rezim parpolnya'. Namun faktanya, kritik tersebut hanya angin lalu. Mereka yang jadi eksekutif tetap saja menduduki jabatan strategis di parpol (Abdul Wahid, 2012:5)

Ketika mesin kekuatan politik di Senayan (DPR) itu membangun kolaborasi, keputusan politik pun 
diniscayakan menjadi produk kompromi. Artinya antar kekuatan politik bisa saling duduk bersama untuk melakukan lobi guna menyepakati pertukaran kepentingan politiknya. Kelompok yang teguh mengajukan impeachment atau kekuatan politik berseberangan, yang jumlahnya tidak memenuhi kuota, bisa gagal total meneruskan peradilan politik impeachment-nya.

Dalam kasus Century, mereka (kelompok pengusul impeachment) itu bisa saja mempunyai bukti memadai seperti rekaman rapat Boediono dengan Sri Mulyani dan pihak-pihak lain, tetapi kuota kekuatan politik merupakan hukum tertinggi dalam sistem politik yang menentukan perlu-tidaknya penegakan peradilan politik yang berisi pendakwaan Boediono.

Kekuatan politik Partai Demokrat di DPR saja, misalnya, sudah berjumlah 138 orang. Kekuatan itu menjadi semakin besar jika ditambah dengan anggota koalisi mereka seperti PKB dan PPP. Dengan persyaratan impeachment harus didukung 2/3 anggota DPR (373 anggota), mustahil impeachment pada Boediono akan bisa dimenangi kekuatan pengusul, kecuali anggota DPR Partai Demokrat mendapat restu dari SBY untuk ramai-ramai mengadili Boediono.

Sebagai suatu ekspektasi dan kewajiban publik ke depan, yang bisa dilakukan tentu saja selain mengharapkan MPR berkeharusan melakukan amendemen konstitusi secara berkelanjutan yang bersubstansi terhadap pematangan impeachment, juga mengingatkan setiap anggota DPR supaya menegakkan khitah demokrasi atau vox populi, vox dei (suara rakyat adalah suara Tuhan) supaya jalan sistem peradilan impeachment tetap terbuka. Suara rakyat (demokrasi) sudah dipercayakan kepadanya untuk ditegakkan dengan segala risiko, bukan dengan segala keuntungan yang bisa diperoleh. Kesejatian pejuang demokrasi bukan ditentukan kemampuan memikirkan 'induk semangnya' (Parpol), tetapi melalui kinerjanya dalam memberikan yang terbaik kepada rakyat. MK Indonesia akan bisa menunjukkan peran fundamentalnya, bilamana DPR secara politik berbasis demokratisasi membuka jalan bagi implementasi sistem peradilan impeachment.

\section{PENUTUP}

\section{Kesimpulan}

MK memegang faktor fundamental dalam sistem peradilan impeachment, bilamana DPR meminta fatwa kepadanya. Kedudukan DPR dalam persidangan MK atau dalam sistem peradilan impeachment adalah sebagai pihak pemohon, karena DPR-lah yang memiliki inisiatif dan berpendapat bahwa Presiden dan/atau Wakil Presiden telah melakukan pelanggaran yang disebutkan dalam Pasal 7A UUD 1945

Putusan yang diberikan oleh MK menjadi bukti, bahwa Indonesia benar-benar sebagai negara yang berbentuk negara hukum. Putusan MK yang berisi fatwa tentang kriteria pelanggaran yang dilakukan oleh Presiden atau Wakil Presiden merupakan putusan yang memosisikan MK sebagai kunci utama yang menentukan tersudutnya atau termakzulkannya posisi dan citra Presiden dan atau Wakil Presiden.

Sistem sangat berliku secara politik dalam ketatanegaraan Indonesia, khususnya dalam memperoleh kesepakatan untuk mengusulkan peradilan mpeachment, yang membuat kewenangan MK dalam konstitusi tidak bisa diimplementasikan hingga kini, layak menjadi bahan pertimbangan bagi MPR untuk melakukan amandemen konstitusi. Amandemen barangkali bisa difokuskan pada besaran persyaratan kuota $2 / 3$ anggota DPR (373 anggota).

\section{Rekomendasi}

MPR diharapkan melakukan amandemen konstitusi secara berkelanjutan yang bersubstansi pematangan impeachment. DPR sebagai lembaga perwakilan rakyat, berani menegakkan suara rakyat yang dipercayakan kepadanya dan berbasis demokrasi ketika meminta fatwa kepada MK.

\section{DAFTAR PUSTAKA}

\section{Buku:}

Amirin, Tatang M. 1996. Pokok-Pokok Teori Sistem. Jakarta: Rajawali Pers.

Aspandi, Ali. 2002. Menggugat Sistem Hukum Peradilan Indonesia yang Penuh Ketidakpastian. Surabaya: LEKSHI (Lembaga Kajian Strategis Hukum Indonesia) dan Lutfansah Mediatama.

Asshiddiqie, Jimly. 2007. Pokok-Pokok Hukum Tata Negara Indonesia. Jakarta: Bhuana Ilmu Populer.

Black, Henry Campbell. 1991. Black's Law Dictionary: Definitions of the Terms and Phrases of American and English Jurisprudence, Ancient and Modern. St. Paul, Minn: West Group.

Majelis Permusyawaratan Republik Indonesia. 2002. Panduan Pemasyarakatan Undang-Undang Dasar Negara Republik Indonesia sesuai 
dengan Urutan Bab, Pasal, dan Ayat. Jakarta: Sekretariat Jenderal MPR RI.

Muflihurrahman. 2012. Quo Vadis Konstitusi. Jakarta: Intan Cendekia.

Mulyosudarmo, Soewoto. 1997. Peralihan Kekuasaan, Kajian Teoritis dan Yuridis terhadap Pidato Nawaksara. Jakarta: Gramedia Pustaka Utama.

Ridwan, Hasyim. 2011. Amandemen Konstitusi dan Hak Asasi Manusia. Surabaya: Visimedia.

Satriya, Bambang. 2012. Hukum Indonesia masih di Simpang Jalan. Jakarta: Nirmana Media.

Soekanto, Soerjono dan Sri Mamudji. 2003. Penelitian Hukum Normatif. Jakarta: Rajagrafindo Persada (Rajawali Grup).

Thalib, Abdul Rasyid. 2006. Wewenang Mahkamah Konstitusi dan Implikasinya dalam Sistem Ketatanegaraan Republik Indonesia. Bandung: Citra Aditya Bakti.

\section{Peraturan Perundang-undangan:}

Undang-Undang Dasar Republik Indonesia 1945.

\section{Website/Jurnal/Koran/Makalah:}

Assidiqy, Jimly. Kedudukan Mahkamah Konstitusi dalam Struktur Ketatanegaraan Indonesia. makalah. diunduh 13 Maret 2013.

. "Struktur Ketatanegaraan Indonesia Setelah Perubahan Keempat UUD Tahun 1945". Makalah Disampaikan Pada Seminar Pembangunan Hukum Nasional VIII Denpasar, 14-18 Juli 2003, http://legal.daily-thought.info. diunduh 14 Maret 2013.

Benny K. Harman. Mahkamah Konstitusi dan Nasib Demokrasi. Kompas (Juli 2003). http: //eprints.ums.ac.id/321/1/5._WINAHYU.pdf. diunduh 13 April 2013.

Biawa, Fidel Dakati. Tanggung Jawab tanpa Impeachment. http://politik.kompasiana.com/ 2010/01/26/tanggungjawab-tanpa-impeachment/. diunduh tanggal 7 April 2013.

Denara, Eldo. Mengenal Impeachment di Indonesia. http://matahatifh.wordpress.com/2010/01/24/ mengenal-impeachment-di-indonesia-oleheldo-denara/. diunduh 4 April 2013.
Gaffar, Janedjri M. Supremasi Konstitusi. Uni Sosial Demokrat, (11 Agustus 2011). http: //www.unisosdem.org/article_detail.php?aid $=10347 \&$ coid $=3 \&$ caid $=21 \&$ gid $=3$. diunduh tanggal 27 Maret 2013.

Harjono. Mekanisme Impeachment dan Hukum Acara Mahkamah Konstitusi. http://id.wikisource.org/ wiki/Mekanisme_Impeachment_\%26_hukumAcara. diunduh 4 April 2013.

Huda, Miftahul.Impeachment. http://www.miftakhulhuda. Com_2010/01/impeachment.html. diunduh 14 Maret 2013.

http://armingsh.blogspot.com/2010/08/istilah-istilahimpeachment.html. diunduh 5 April 2013.

http://rippleworld.wordpress.com/2010/03/18/tujuanamandemen-uud-1945/. diunduh 15 Pebruari 2013.

http://www.mahkamahkonstitusi.go.id/ File\%20Publikasi/KI_Impeachment.pdf. diunduh 4 April 2013.

http://www.negarahukum.com/hukum/sistem-peradilanpasca-perubahan-uud-1945.html. diunduh 13 Maret 2013

Indonesia Law Reform, http:/litigasi.blogspot.com/2008/ 03/urgensi-amandemen-uud-1945-jurnal.html. diunduh 21 Maret 2013.

Indrayana, Denny. Urgensi Komisi Konstitusi. http: //els.bappenas.go.id/upload/other/Urgensi\%20 Komisi\%20Konstitusi.html. diunduh 15 April 2013.

Syafaat, Mohammad Ali. Hukum Acara Memutus Pendapat DPR dalam Proses Pemberhentian Presiden dan/atau Wakil Presiden dalam Masa Jabatannya. http://safaat.lecture.ub.ac.id/files/ 2011/11/Bab-IX-Impeachment.pdf. diunduh 19 Maret 2013.

Wahid, Abdul. Dari Simposium Internasional: Belajar Menghormati Putusan Mahkamah Konstitusi. Jurnal Konstitusi Kerjasama antara Pusat Kajian Konstitusi Fakultas Hukum Universitas Islam Malang dengan Mahkamah Konstitusi. Jakarta. 2011. h. 65.

Wahid, Abdul. Impeachment dan Khittah Demokrasi. Media Indonesia. 30 November 2012. 